Molecules 2010, 15, 6588-6597; doi:10.3390/molecules15096588

OPEN ACCESS

molecules

ISSN 1420-3049

www.mdpi.com/journal/molecules

Article

\title{
Synthesis of Chiral Macrocyclic or Linear Pyridine Carboxamides from Pyridine-2,6-dicarbonyl Dichloride as Antimicrobial Agents
}

\author{
Rashad A. Al-Salahi, Mohamed A. Al-Omar and Abd El-Galil E. Amr * \\ Department of Pharmaceutical Chemistry, College of Pharmacy, King Saud University, Riyadh 11451, \\ Saudi Arabia
}

* Author to whom correspondence should be addressed; E-Mail: aamr1963@yahoo.com.

Received: 26 August 2010; in revised form: 6 September 2010 / Accepted: 7 September 2010 /

Published: 20 September 2010

\begin{abstract}
A series of chiral linear and macrocyclic bridged pyridines has been prepared starting from pyridine-2,6-dicarbonyl dichloride (2). The coupling of 1 with D-alanyl methyl ester gave 2,6-bis-D-alanyl pyridine methyl ester (3). Hydrazinolysis of $\mathbf{3}$ with hydrazine hydrate afforded bis-hydrazide 4 . The latter was reacted with thiophene-2carbaldehyde, phthalic anhydride or cyclohexanone to afford bis-carboxamide pyridine derivatives 5-7, respectively. Compound 4 was coupled with $p$-methoxy- or $p$-nitroacetophenone to yield compounds 8 and 9. In addition, 4 was reacted with 1,2,4,5-benzenetetracarboxylic acid dianhydride or 1,4,5,8-naphthalenetetracarboxylic acid dianhydride to afford the macrocyclic octacarboxaamide pyridines $\mathbf{1 0}$ and 11. The detailed synthesis, spectroscopic data and antimicrobial screening for the synthesized compounds are reported.
\end{abstract}

Keywords: synthesis; chiral macrocyclic; pyridine-2,6-dicarbonyl dichloride; antimicrobial activity

\section{Introduction}

Synthesis of chemical modifications of existing antibacterial agents in order to generate novel molecules with better therapeutic properties is necessary because of the emergence of multidrug resistant bacteria [1]. In continuation of our previous investigations [2-4], we have previously reported 
the synthesis and biological activity screening of some dipicolinic acid bis-L-amino acid hydrazide derivatives [3] and their corresponding acids [5]. Compounds of this kind have attracted considerable attention as inhibitors of ribonucleoside diphosphate reductase [6]. Synthetic macrocyclic peptides are still the subject of intensive research with respect to their therapeutic applications [7], as well as their binding properties [8]. We also demonstrated that some peptido-heterocyclic derivatives exhibit a general ionophoric potency towards divalent cations [9] and are useful for assembling novel thiocyanate-selective membrane sensors [10]. On the other hand, Schiff base and other heterocyclic derivatives were reported to possess diverse biological activities, such as antibacterial [11-14] and anti-inflammatory [15-17] properties. Recently, we have demonstrated the significance of 2,6-disubstituted pyridine derivatives as biologically active congeners [18-23]. In view of these observations and as a continuation of our previous work in peptido-heterocyclic chemistry, we have synthesized some new compounds containing amino acid and hetero-organic moieties, and tested them for selected biological activities.

\section{Results and Discussion}

\subsection{Chemistry}

D-Alanyl methyl ester was initially coupled with 2,6-dipicolinic acid (1) (Mixed Anhydride Method, Method A] [5] or with pyridine-2,6-dicarboyl dichloride (2) via the conventional acid chloride method (Methid B) [3] to give the corresponding bis-ester 3. Hydrazinolysis of $\mathbf{3}$ with hydrazine hydrate in absolute ethanol afforded the corresponding bis-hydrazide 4 (Scheme 1).

Scheme 1. Synthetic routes to compounds 3 and 4.

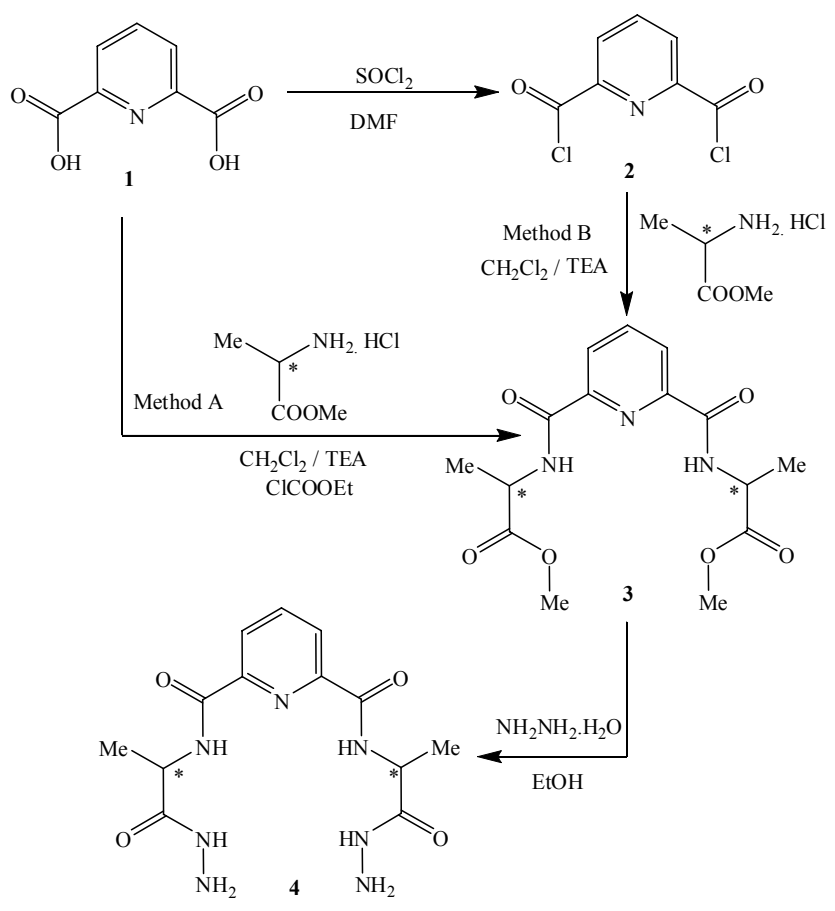


The reaction of bishydrazide 4 with thiophene-2-carbaldehyde in refluxing ethanol afforded the corresponding hydrazone 5, but when it was reacted with phthalic anhydride in refluxing glacial acid it gave the corresponding imide 6. In a similar way, treatment of bis-hydrazide 4 with carbonyl compounds, namely, cyclohexanone, $p$-methoxyacetophenone or $p$-nitroacetophenone in refluxing ethanol in the presence of few drops of glacial acetic acid afforded the corresponding bis-(cyclohexyl tetraamide)pyridine derivative 7, bis-(substituted aryl tetraamide)pyridine derivatives 8 and $\mathbf{9}$, respectively (Scheme 2 ).

Scheme 2. Synthetic routes to compounds 5-9.<smiles>CC(NC(=O)c1cccc(C(=O)N[C@@H](C)C(=O)N/N=C/c2cccs2)n1)C(=O)N/N=C/c1cccs1</smiles><smiles>CC(NC(=O)c1cccc(C(=O)N[C@@H](C)C(=O)NN2C(=O)c3ccccc3C2=O)n1)C(=O)NN1C(=O)c2ccccc2C1=O</smiles><smiles>O=Cc1cccs1</smiles><smiles>[X]c1ccc(C(C)=O)cc1</smiles><smiles>CCOC(=O)OCCCCCCCCC(=O)NC(C)C(=O)NN=C1CCCCC1</smiles><smiles>[X][X]O[Na]</smiles> 
Condensation of the same hydrazide 4 with selected tetraacid dianhydrides, namely, 1,2,4,5benzenetetracarboxylic acid dianhydride or 1,4,5,8-naphthalenetetracarboxylic acid dianhydride in refluxing acetic acid afforded the corresponding macrocyclic octaamide-tetraimide pyridine derivatives 10 and 11, respectively (Scheme 3).

Scheme 3. Synthetic routes to compounds $\mathbf{1 0}$ and $\mathbf{1 2}$.

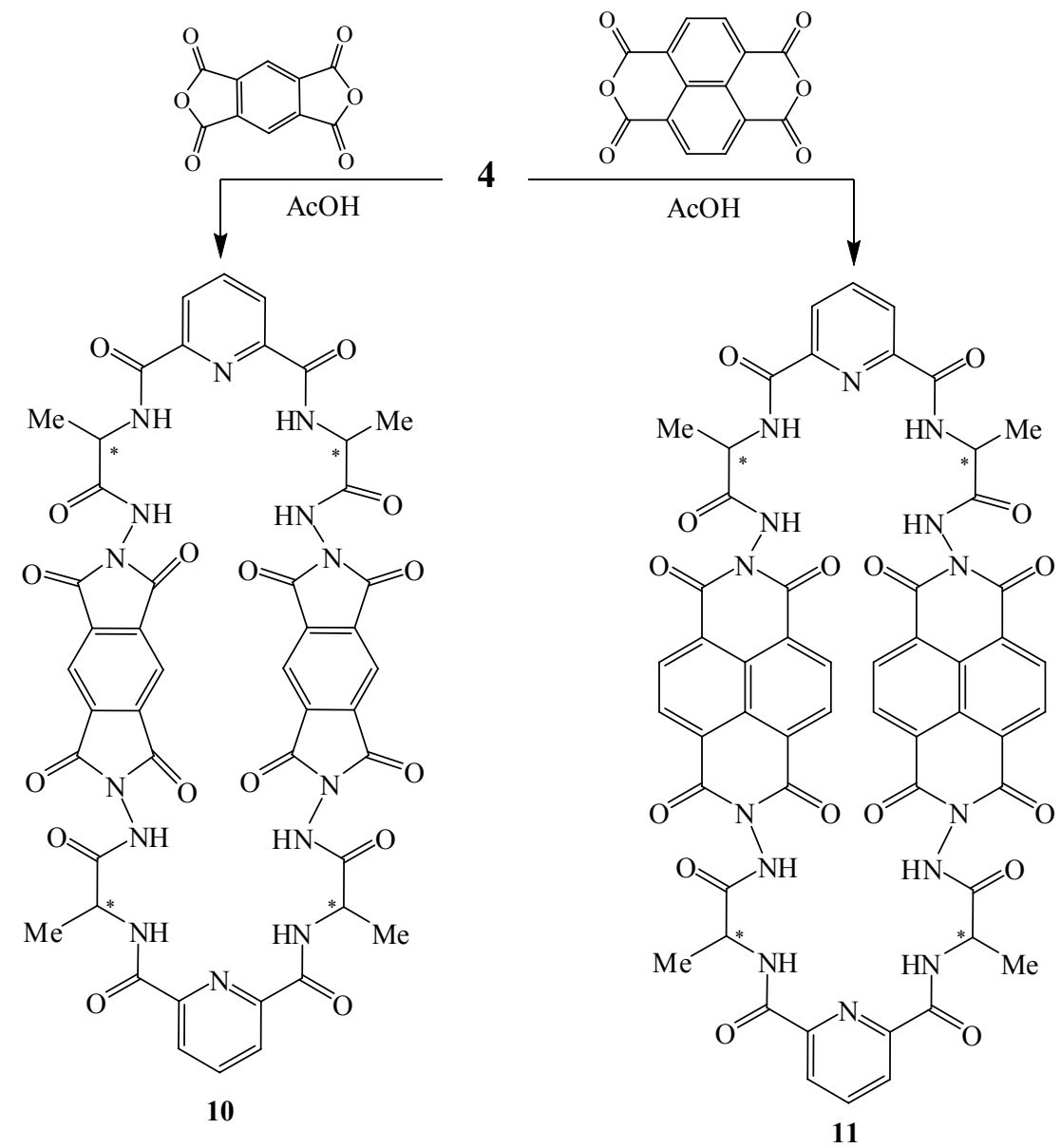

Table 1. Melting points, crystallization solvents, yields, molecular formulae and molecular weights of compounds 3-9.

\begin{tabular}{|c|c|c|c|c|c|}
\hline $\begin{array}{l}\text { Comp } \\
\text {. No. }\end{array}$ & $\begin{array}{l}\mathrm{Mp} \\
\left({ }^{\circ} \mathrm{C}\right)\end{array}$ & $\begin{array}{l}\text { Cryst. } \\
\text { Solv. }\end{array}$ & $\begin{array}{c}\text { Yield } \\
(\%)\end{array}$ & $\begin{array}{c}{[\alpha]^{30} \mathrm{D}} \\
{[\mathrm{MeOH}]}\end{array}$ & $\begin{array}{l}\text { Molecular Formula } \\
\text { (Mol. Wt.) }\end{array}$ \\
\hline 3 & $148-250$ & EtOH/diethyl ether & $75[\mathrm{~A}] ; 80[\mathrm{~B}]$ & +68 & $\mathrm{C}_{15} \mathrm{H}_{19} \mathrm{~N}_{3} \mathrm{O}_{6}(337.13)$ \\
\hline 4 & 193-195 & EtOH & 76 & +45 & $\mathrm{C}_{13} \mathrm{H}_{19} \mathrm{~N}_{7} \mathrm{O}_{4}$ (337.33) \\
\hline 5 & $157-159$ & $\mathrm{EtOH}$ & 65 & +32 & $\mathrm{C}_{23} \mathrm{H}_{23} \mathrm{~N}_{7} \mathrm{O}_{4} \mathrm{~S}_{2}(525.60)$ \\
\hline 6 & $302-304$ & $\mathrm{AcOH} /$ ether & 80 & +8 & $\mathrm{C}_{29} \mathrm{H}_{23} \mathrm{~N}_{7} \mathrm{O}_{8}$ (597.54) \\
\hline 7 & $135-137$ & EtOH/diethylether & 65 & +18 & $\mathrm{C}_{25} \mathrm{H}_{35} \mathrm{~N}_{7} \mathrm{O}_{4}$ (497.59) \\
\hline 8 & $139-140$ & EtOH & 70 & +34 & $\mathrm{C}_{31} \mathrm{H}_{35} \mathrm{~N}_{7} \mathrm{O}_{6}(601.65)$ \\
\hline 9 & $152-154$ & EtOH & 65 & +54 & $\mathrm{C}_{29} \mathrm{H}_{29} \mathrm{~N}_{9} \mathrm{O}_{8}(631.60)$ \\
\hline 10 & $201-203$ & $\mathrm{DMF} / \mathrm{H}_{2} \mathrm{O}$ & 60 & +24 & $\mathrm{C}_{46} \mathrm{H}_{34} \mathrm{~N}_{14} \mathrm{O}_{16}(1038.85)$ \\
\hline 11 & $232-234$ & $\mathrm{DMF} / \mathrm{H}_{2} \mathrm{O}$ & 65 & +16 & $\mathrm{C}_{54} \mathrm{H}_{38} \mathrm{~N}_{14} \mathrm{O}_{16}$ (1138.96) \\
\hline
\end{tabular}

The structures of newly synthesized compounds 3-11 were confirmed by IR, ${ }^{1} \mathrm{H}-\mathrm{NMR},{ }^{13} \mathrm{C}-\mathrm{NMR}$ and mass spectra. 


\subsection{Antimicrobial Testing}

Preliminary biological activity screening of the synthesized compounds at $50 \mu \mathrm{g} / \mathrm{mL}$ has been performed against microorganisms representing Gram-positive bacteria (Bacillus subtilis and Staphylococcus aureus), Gram-negative bacteria (Escherichia coli) and fungi (Candida albicans), using the bioassay technique of antibiotics [24] specified in US Pharmacopeia. From Table 2, it appears that the synthesized compounds 3-11 have significant antimicrobial activities, with 5, 6, 7, 9, 10 and 11 having higher antimicrobial activities than that of the other prepared compounds. On the other hand, compounds 3, 5, 7, 9, 10 and 11 exhibited interesting high antifungal activities, in addition to their antibacterial activities. Ciprofloxacin and ketaconazole were used as antibacterial and antifungal reference drugs, respectively.

Table 2. Antimicrobial activities of the new synthesized compounds 3-11.

\begin{tabular}{|c|c|c|c|c|}
\hline \multirow{3}{*}{ Compound No. } & \multicolumn{4}{|c|}{ Inhibition zone in $\mathrm{mm}($ at $50 \mu \mathrm{g} / \mathrm{mL}$ ) } \\
\hline & \multicolumn{2}{|c|}{ Gram positive bacteria } & \multirow{2}{*}{$\begin{array}{c}\text { Gram negative bacteria } \\
\text { Escherichia coli }\end{array}$} & \multirow{2}{*}{$\frac{\text { Fungi }}{\text { C. albicans }}$} \\
\hline & Bacillus subtilis & S. aureus & & \\
\hline 1 & 14 & 18 & 19 & -ve \\
\hline 3 & 16 & 20 & 14 & 16 \\
\hline 4 & 14 & 18 & 19 & -ve \\
\hline 5 & 25 & 25 & 20 & 17 \\
\hline 6 & 23 & 25 & 30 & -ve \\
\hline 7 & 19 & 22 & 21 & 20 \\
\hline 8 & 13 & 19 & 16 & -ve \\
\hline 9 & 20 & 25 & 24 & 14 \\
\hline 10 & 19 & 24 & 20 & 16 \\
\hline 11 & 20 & 22 & 21 & 15 \\
\hline Ciprofloxacin & 23 & 23 & 25 & $-\mathrm{ve}$ \\
\hline Ketaconazole & $-\mathrm{ve}$ & $-\mathrm{ve}$ & -ve & 23 \\
\hline
\end{tabular}

\subsection{Structure-Activity Relationship (SAR)}

From the results above (Table 2), we can conclude that pyridine and amide moieties are essential for antimicrobial activity. In the present work, we can suggest that the antimicrobial activity is due to:

- The presence of nitrogen heterocyclic rings.

- The presence of the amide linkage groups generally enhancing the activity.

- The difference in activity between the compounds which is due to the indicated subsistents in the used reagents of the molecule.

\section{Experimental}

\subsection{General}

Melting points $\left({ }^{\circ} \mathrm{C}\right)$ were measured in open glass capillaries using a Barnstead 9001 Electrothermal melting point apparatus and are uncorrected. NMR spectra were obtained on a Bruker AC 500 Ultra Shield NMR spectrometer (Bruker, Fällanden, Switzerland) operating at $500 \mathrm{MHz}$ for ${ }^{1} \mathrm{H}$ and 125 $\mathrm{MHz}$ for ${ }^{13} \mathrm{C}$; the chemical shifts are expressed in $\delta$ (ppm) downfield from tetramethylsilane (TMS) 
used as internal standard. Electrospray ionization mass spectra (ESI-MS) were recorded on a Waters QuatroMicro triple quadrupole tandem mass spectrometer at 4.0 and $3.5 \mathrm{kV}$ for positive and negative ions, respectively. Elemental analyses $(\mathrm{C}, \mathrm{H}, \mathrm{N}, \mathrm{Cl}, \mathrm{S})$ were in full agreement with the proposed structures within $\pm 0.4 \%$ of the theoretical values. Monitoring the reactions and checking the purity of the final products were carried out by thin layer chromatography (TLC) using silica gel precoated aluminum sheets (60 F254, Merck) and visualization with ultraviolet light (UV) at 365 and $254 \mathrm{~nm}$.

\subsection{Chemistry}

\subsubsection{Synthesis of 2,6-bis-(methyl-D-alanylcarbonyl)pyridine carboxylate (3)}

Method A: To a stirred cold mixture $\left(-15^{\circ} \mathrm{C}\right)$ of 2,6-pyridine dicarboxylic acid $(1,0.167 \mathrm{~g}, 1 \mathrm{mmol})$ in cold dry tetrahydrofuran $(100 \mathrm{~mL})$ and ethyl chloroformate $(0.216 \mathrm{~g}, 2 \mathrm{mmol})$, triethylamine $(0.202 \mathrm{~g}$, $2 \mathrm{mmol})$ was added, then after $10 \mathrm{~min}$., D-alanyl methyl ester $(0.206 \mathrm{~g}, 2 \mathrm{mmol})$ was added. The reaction mixture was stirred at $-15{ }^{\circ} \mathrm{C}$ for $3 \mathrm{~h}$ then for $12 \mathrm{~h}$ at r.t. The formed triethylamine hydrochloride was filtered off, and the solvent was evaporated under reduced pressure. The obtained residue was dissolved in $150 \mathrm{~mL}$ dichloromethane, washed with water, $1 \mathrm{~N}$ hydrochloric acid, $1 \mathrm{~N}$ sodium bicarbonate and finally with water and dried over anhydrous calcium chloride. Solvent was evaporated under reduced pressure to dryness and the obtained solid was crystallized to give $\mathbf{3}$.

Method B: To a solution of D-alanyl methyl ester (0.206 g, $2 \mathrm{mmol})$, pyridine-2,6-dicarbonyl dichloride $(2,0.204 \mathrm{~g}, 1 \mathrm{mmol})$ in dichloromethane $(15 \mathrm{~mL})$ was added at $-10{ }^{\circ} \mathrm{C}$ with stirring. Triethylamine $(0.2 \mathrm{~mL}, 2 \mathrm{mmol})$ was added dropwise to the reaction mixture with stirring in order to keep the reaction mixture slightly basic $(\mathrm{pH} \sim 8)$. Stirring was maintained for 3 hours at $\left(-15^{\circ} \mathrm{C}\right)$ and $12 \mathrm{~h}$ at r.t.. The reaction mixture was then washed with water, $1 \mathrm{~N}$ hydrochloric acid, $1 \mathrm{~N}$ sodium bicarbonate and finally with water and dried over anhydrous calcium chloride. Solvent was evaporated under reduced pressure to dryness and the obtained solid was crystallized to give 3 . IR $\left(\mathrm{KBr}, \mathrm{cm}^{-1}\right): v$ $3284(\mathrm{NH}), 1742(\mathrm{C}=\mathrm{O}), 1680(\mathrm{C}=\mathrm{O}) .{ }^{1} \mathrm{H}-\mathrm{NMR}\left(\mathrm{DMSO}_{\mathrm{d}}\right): \delta 1.56\left(\mathrm{~d}, 6 \mathrm{H}, 2 \mathrm{CH}_{3}\right), 3.80(\mathrm{~s}, 6 \mathrm{H}$, $\left.2 \mathrm{OCH}_{3}\right), 4.70-4.81(\mathrm{~m}, 2 \mathrm{H}, 2 \mathrm{CH}), 8.05\left(\mathrm{~s}, 2 \mathrm{H}, 2 \mathrm{NH}\right.$ exchangeable with $\left.\mathrm{D}_{2} \mathrm{O}\right), 8.29-8.37(\mathrm{~m}, 3 \mathrm{H}$, pyrid-H). ${ }^{13} \mathrm{C}-\mathrm{NMR}: 18.20,48.31,52.60,125.19,138.93,148.35,162.89,173.28 . \mathrm{MS}, \mathrm{m} / \mathrm{z}(\%): 337$ $\left(\mathrm{M}^{+}, 4\right), 306$ (24), 275 (100), 204 (36), 133 (18), 105 (65), 77 (86).

N2,N6-Bis(1-hydrazinyl-1-oxopropan-2-yl)pyridine-2,6-dicarboxamide (4). A mixture of 3 (0.24 g, $1 \mathrm{mmol})$ and hydrazine hydrate $(0.8 \mathrm{~mL}, 16 \mathrm{mmol})$ in absolute ethanol $(50 \mathrm{~mL})$ was refluxed for $6 \mathrm{~h}$. Excess solvent was evaporated under reduced pressure to dryness and the obtained residue was triturated with ethanol, the obtained solid was crystallized to give 4. IR $\left(\mathrm{KBr}, \mathrm{cm}^{-1}\right)$ : v 3853-3280 (NH, $\left.\mathrm{NH}_{2}\right), 1661(\mathrm{C}=\mathrm{O}) .{ }^{1} \mathrm{H}-\mathrm{NMR}\left(\mathrm{DMSO}_{-} \mathrm{d}_{6}\right): \delta 1.44\left(\mathrm{~d}, 6 \mathrm{H}, 2 \mathrm{CH}_{3}\right), 2.51\left(\mathrm{~s}, 4 \mathrm{H}, 2 \mathrm{NH}_{2}\right.$, exchangeable with $\left.\mathrm{D}_{2} \mathrm{O}\right), 4.52-4.55(\mathrm{~m}, 2 \mathrm{H}, 2 \mathrm{CH}), 8.15-8.21(\mathrm{~m}, 3 \mathrm{H}$, pyrid-H), $9.16(\mathrm{~d}, 2 \mathrm{H}, 2 \mathrm{NH}$ exchangeable with $\left.\mathrm{D}_{2} \mathrm{O}\right), 9.27$ (s, 2H, $2 \mathrm{NH}$ exchangeable with $\left.\mathrm{D}_{2} \mathrm{O}\right) .{ }^{13} \mathrm{C}$ NMR: 17.90, 47.54, 124.52, 139.18, 148.74, 162.93, 171.19. MS, m/z (\%): $339\left(\mathrm{M}^{+}+2,100\right), 306$ (32), 275 (56), 235 (44), 133 (100), 105 (72), 102 (65).

N2,N6-Bis(1-oxo-1-(2-(thiophen-2-ylmethylene)hydrazinyl)propan-2-yl)pyridine-2,6-dicarboxamide

(5). A solution of $4(0.34 \mathrm{~g}, 1 \mathrm{mmol})$ and thiophene-2-carbaldehyde $(0.224 \mathrm{~g}, 2 \mathrm{mmol})$ in absolute 
ethanol $(100 \mathrm{~mL})$ was refluxed for $6 \mathrm{~h}$. The solvent was concentrated under reduced pressure, the obtained solid was filtered off, dried and crystallized to afford 5. IR $\left(\mathrm{KBr}, \mathrm{cm}^{-1}\right): v 3854-3676(\mathrm{NH})$, $1669(\mathrm{C}=\mathrm{O}) .{ }^{1} \mathrm{H}-\mathrm{NMR}\left(\mathrm{DMSO}_{-} \mathrm{d}_{6}\right): \delta 1.50\left(\mathrm{~d}, 6 \mathrm{H}, 2 \mathrm{CH}_{3}\right), 4.56-4.57(\mathrm{~m}, 2 \mathrm{H}, 2 \mathrm{CH}), 7.18,7.19(\mathrm{~s}, 2 \mathrm{H}$, $2 \mathrm{CH}=\mathrm{N}), 7.44-7.73(\mathrm{~m}, 6 \mathrm{H}, \mathrm{Ar}-\mathrm{H}), 8.20-8.32(\mathrm{~m}, 3 \mathrm{H}$, pyrid-H), 9.14, $9.63(2 \mathrm{~s}, 4 \mathrm{H}, 4 \mathrm{NH}$ exchangeable with $\left.\mathrm{D}_{2} \mathrm{O}\right) .{ }^{13} \mathrm{C}$ NMR: 14.06, 16.68, 48.22, 60.62, 124.78, 125.03, 125.16, 128.01, 128.25, 128.81, $129.33,130.97,131.51,133.76,139.05,139.41,139.73,145.52,148.32,155.77,159.55,163.10$, 172.33. MS, m/z (\%): 523 (M+2, 2), 510 (4), 480 (5), 457 (3), 355 (8), 221 (100), 207 (12), 193 (15), 150 (45), 105 (18), 94 (5), 78 (15).

N2,N6-Bis(1-(1,3-dioxoisoindolin-2-ylamino)-1-oxopropan-2-yl)-pyridine-2,6-dicarboxamide (6). A suspension of $4(0.34 \mathrm{~g}, 1 \mathrm{mmol})$ and phthalic anhydride $(0.3 \mathrm{~g}, 2 \mathrm{mmol})$ in glacial acetic acid $(50 \mathrm{~mL})$ was refluxed for $3 \mathrm{~h}$. The solvent was evaporated under reduced pressure, the residue was solidified with diethyl ester. The obtained solid was filtered off, dried and crystallized to give 6 . IR $\left(\mathrm{KBr}, \mathrm{cm}^{-1}\right)$ : v 3853-3675 (NH), $1661(\mathrm{C}=\mathrm{O}) .{ }^{1} \mathrm{H}-\mathrm{NMR}\left(\mathrm{DMSO}_{\mathrm{d}}\right)$ : $\delta 1.60\left(\mathrm{~d}, 6 \mathrm{H}, 2 \mathrm{CH}_{3}\right), 3.36-3.50(\mathrm{~m}, 2 \mathrm{H}, 2 \mathrm{CH})$, 7.88-8.07 (m, 8H, Ar-H), 8.23-8.42 (m, 3H, pyrid-H), 9.81, 9.99 (2s, 4H, 4NH exchangeable with $\left.\mathrm{D}_{2} \mathrm{O}\right) .{ }^{13} \mathrm{C}$ NMR: 20.48, 47.18, 123.72, 124.05, 124.90, 129.40, 135.30, 135.32, 160.20, 167.92, 171.90. MS, m/z (\%): $597\left(\mathrm{M}^{+}, 0.16\right), 569$ (12), 462 (5), 433 (4), 413 (8), 278 (6), 267 (6), 207 (45), 162 (55), 104 (100), 78 (18), 55 (20).

N2,N6-Bis(1-(2-cyclohexylidenehydrazinyl)-1-oxopropan-2-yl)pyridine-2,6-dicarboxamide (7). To a solution of cyclohexanone $(0.196 \mathrm{~g}, 2 \mathrm{mmol})$ in absolute ethanol $(50 \mathrm{~mL})$ in the presence of few drops glacial acetic acid, compound $4(0.34 \mathrm{~g}, 1 \mathrm{mmol})$ was added with stirring. The reaction mixture was heated under reflux for $6 \mathrm{~h}$, and evaporated under reduced pressure to dryness. The obtained residue was solidified with n-hexane, the solid formed was filtered off, dried and crystallized to give 7. IR $\left(\mathrm{KBr}, \mathrm{cm}^{-1}\right): v 3268(\mathrm{NH}), 2934$ (CH-aliphatic), $1664(\mathrm{C}=\mathrm{O}) .{ }^{1} \mathrm{H}-\mathrm{NMR}\left(\mathrm{DMSO}-\mathrm{d}_{6}\right): \delta 1.56(\mathrm{~d}, 6 \mathrm{H}$, $\left.2 \mathrm{CH}_{3}\right), 1.62-1.65$ (m, $6 \mathrm{H}, 3 \mathrm{CH}_{2}$, cyclohexyl ring), 2.28-2.30 (m, 4H, 2 $\mathrm{CH}_{2}$, cyclohexyl ring), 3.66-3.76 $(\mathrm{m}, 2 \mathrm{H}, 2 \mathrm{CH}), 8.25-8.56\left(\mathrm{~m}, 3 \mathrm{H}\right.$, pyrid-H), 8.96, $10.15\left(2 \mathrm{~s}, 4 \mathrm{H}, 4 \mathrm{NH}\right.$ exchangeable with $\left.\mathrm{D}_{2} \mathrm{O}\right) .{ }^{13} \mathrm{C}$ NMR: $15.80,23.85,26.45,35.10,46.96,124.58,139.08,148.14,162.42,163.65,172.25$. MS, $\mathrm{m} / \mathrm{z}(\%)$ : $497\left(\mathrm{M}^{+}, 0.1\right), 480(0.1), 465$ (0.2), 238 (16), 220 (100), 192 (55), 146 (35), $110(62), 45$ (54).

3.2.2. Synthesis of N2,N6-Bis(1-(2-(1-(4-substituted-phenyl)ethylidene)hydrazinyl)-1-oxopropan-2yl)pyridine-2,6-dicarboxamides 8 and 9

A mixture of 4 (0.34 g, $1 \mathrm{mmol})$ and an acetophenone derivative, namely, $p$-methoxy- or $p$-nitroacetophenenone $(2 \mathrm{mmol})$ in absolute ethanol $(100 \mathrm{~mL})$ was refluxed for $6 \mathrm{~h}$ in the presence of glacial acetic acid $(2 \mathrm{~mL})$. The reaction mixture was concentrated under reduced pressure, the solid formed was collected by filtration, and purified by crystallization to give 8 and 9 .

N2,N6-Bis(1-(2-(1-(4-methoxyphenyl)ethylidene)hydrazinyl)-1-oxopropan-2-yl)pyridine-2,6-dicarboxamide (8). IR (KBr, cm $\left.{ }^{-1}\right)$ : $v 3269(\mathrm{NH}), 2997$ (CH-aliphatic), $1663(\mathrm{C}=\mathrm{O}) .{ }^{1} \mathrm{H}-\mathrm{NMR}\left(\mathrm{DMSO}-\mathrm{d}_{6}\right): \delta$ 1.36-1.42 (m, 6H, 2CH $), 1.68\left(\mathrm{~s}, 6 \mathrm{H}, 2 \mathrm{CH}_{3}\right), 3.68\left(\mathrm{~s}, 6 \mathrm{H}, 2 \mathrm{OCH}_{3}\right), 4.22-4.28(\mathrm{~m}, 2 \mathrm{H}, 2 \mathrm{CH}), 7.42-7.84$ $(\mathrm{m}, 8 \mathrm{H}, \mathrm{Ar}-\mathrm{H}), 8.16-8.34\left(\mathrm{~m}, 3 \mathrm{H}\right.$, pyrid-H) $, 9.34,10.05\left(2 \mathrm{~s}, 4 \mathrm{H}, 4 \mathrm{NH}\right.$ exchangeable with $\left.\mathrm{D}_{2} \mathrm{O}\right) .{ }^{13} \mathrm{C}$ 
NMR: $17.60,18.15,52.95,56.84,114.05,126.12,129.65,124.80,138.96,149.55,161.85,162.32$, 168.70, 177.80. MS, m/z (\%): $601\left(\mathrm{M}^{+}, 10\right), 552$ (1), 512 (2), 252 (12), 235 (10), 221 (100), 193 (25), 178 (24), $150(54), 78$ (15).

N2,N6-Bis(1-(2-(1-(4-nitrophenyl)ethylidene)hydrazinyl)-1-oxopropan-2-yl)pyridine-2,6-dicarboxamide (9). IR (KBr, cm $\left.{ }^{-1}\right): v 3311(\mathrm{NH}), 1669(\mathrm{C}=\mathrm{O}) .{ }^{1} \mathrm{H}-\mathrm{NMR}\left(\mathrm{DMSO}-\mathrm{d}_{6}\right): \delta 1.42-1.48(\mathrm{~m}, 6 \mathrm{H}$, $\left.2 \mathrm{CH}_{3}\right), 1.72\left(\mathrm{~s}, 6 \mathrm{H}, 2 \mathrm{CH}_{3}\right), 4.18-4.30(\mathrm{~m}, 2 \mathrm{H}, 2 \mathrm{CH}), 7.24-7.85(\mathrm{~m}, 8 \mathrm{H}, \mathrm{Ar}-\mathrm{H}), 8.22-8.42(\mathrm{~m}, 3 \mathrm{H}$, pyrid-H), 9.40, $10.15\left(2 \mathrm{~s}, 4 \mathrm{H}, 4 \mathrm{NH}\right.$ exchangeable with $\left.\mathrm{D}_{2} \mathrm{O}\right) .{ }^{13} \mathrm{C}$ NMR: $17.45,18.23,52.88,56.85$, $114.35,125.98,129.48,125.10,138.92,148.95,162.05,162.40,168.65,176.95 . \mathrm{MS}, \mathrm{m} / \mathrm{z}(\%): 631$ $\left(\mathrm{M}^{+}, 8\right), 585$ (4), 537 (6), 509 (12), 357 (8), 275 (100), 245 (35), 189 (62), 133 (46), 77 (48).

\subsubsection{Synthesis of macrocyclic octaamide tetraimides $\mathbf{1 0}$ and $\mathbf{1 1}$}

A suspension of 4 ( $0.34 \mathrm{~g}, 1 \mathrm{mmol})$ and 1,2,4,5-benzenetetracarboxylic acid dianhydride or 1,4,5,8naphthalene tetracarboxylic acid dianhydride $(1 \mathrm{mmol})$ in acetic acid $(50 \mathrm{~mL})$ was refluxed for $7 \mathrm{~h}$. The obtained solid was collected by filtration, and crystallized to give $\mathbf{1 0}$ and $\mathbf{1 1}$.

Macrocyclic octaamide tetraimide 10. IR $\left(\mathrm{KBr}, \mathrm{cm}^{-1}\right): v$ 3853-3675 (NH), 1661-1668 $(\mathrm{C}=\mathrm{O}) .{ }^{1} \mathrm{H}-\mathrm{NMR}$ $\left(\mathrm{DMSO}_{-} \mathrm{d}_{6}\right): \delta 1.42-1.72\left(\mathrm{~m}, 12 \mathrm{H}, 4 \mathrm{CH}_{3}\right), 3.54-3.68(\mathrm{~m}, 4 \mathrm{H}, 4 \mathrm{CH}), 7.75(\mathrm{~s}, 4 \mathrm{H}, \mathrm{Ar}-\mathrm{H}), 8.18-8.30(\mathrm{~m}$, $6 \mathrm{H}, 2$ pyrid-H), 9.78, 10.05 (2s, 8H, 8NH exchangeable with $\left.\mathrm{D}_{2} \mathrm{O}\right) .{ }^{13} \mathrm{C}$ NMR: $18.95,48.05,123.88$, 124.92, 129.52, 135.45, 136.10, 161.20, 168.92, 174.90. MS, m/z (\%): $1038\left(\mathrm{M}^{+}, 2\right), 1021(4), 1006$ (15), 237 (25), 182 (75), 162 (10), 112 (20), 92 (55), 59 (72), 43 (100).

Macrocyclic octaamide tetraimide 11. IR $\left(\mathrm{KBr}, \mathrm{cm}^{-1}\right): v$ 3862-3578 (NH), 1665-1668 $(\mathrm{C}=\mathrm{O}) .{ }^{1} \mathrm{H}-\mathrm{NMR}$ (DMSO-d ${ }_{6}$ ): $\delta 1.38-1.90\left(\mathrm{~m}, 12 \mathrm{H}, 4 \mathrm{CH}_{3}\right), 3.65-3.72(\mathrm{~m}, 4 \mathrm{H}, 4 \mathrm{CH}), 8.05-7.75(\mathrm{~m}, 8 \mathrm{H}, \mathrm{Ar}-\mathrm{H}), 8.23-8.35$ $\left(\mathrm{m}, 6 \mathrm{H}, 2\right.$ pyrid-H) $9.85,10.15\left(2 \mathrm{~s}, 8 \mathrm{H}, 8 \mathrm{NH}\right.$ exchangeable with $\left.\mathrm{D}_{2} \mathrm{O}\right) .{ }^{13} \mathrm{C}$ NMR: 17.95, 51.15, $119.68,123.45,134.75,138.23,138.78,148.75,157.86,160.05,172.18 . \mathrm{MS}, \mathrm{m} / \mathrm{z}(\%): 1138\left(\mathrm{M}^{+}, 2\right)$, 1124 (4), 1067 (15), 863 (12), 569 (8), 295 (10), 275 (100), 204 (75), 133 (35), 59 (78).

\section{Conclusions}

A series of chiral linear and macrocyclic bridged pyridines has been prepared starting from pyridine-2,6-dicarbonyl dichloride (2). The structure assignments of the new compounds are based on chemical and spectroscopic evidence. The newly synthesized compounds 3-11 have been screened for their bactericidal and fungicidal activities. Among them compounds 5, 6, 7, 9, 10 and 11 have antimicrobial activities higher than that of the other prepared compounds. On the other hand, compounds 3, 5, 7, 9, 10 and 11 also exhibited interesting high antifungal activities in addition to their antibacterial activities. Ciprofloxacin and ketaconazole were used as antibacterial and antifungal reference drugs, respectively. 


\section{Acknowledgements}

The financial support of the Research Center of the College of Pharmacy, King Saud University is greatly appreciated. The kind help of El-Sayed E. Mostafa, Department of Microbial Chemistry, National Research Center, Cairo, Egypt, for carrying out the antimicrobial screening is highly appreciated.

\section{References and Notes}

1. Chu, T.D.W.; Plattner, J.J.; Kotz, L. New directions in antibacterial research. J. Med. Chem. 1996, 39, 3853-3874.

2. Abou-Ghalia, M.H.; Amr, A.E. Synthesis and investigation of a new cyclo- $\left(\mathrm{N}^{\alpha}-\right.$ dipicolinoyl)pentapeptide of a breast and CNS cytotoxic activity and an ionophoric specifity. Amino Acids 2004, 26, 283-289.

3. Amr, A.E.; Abdel-Salam, O.I.; Attia, A.; Stibor, I. Synthesis of new potential bis-intercallators based on chiral pyridine-2,6-dicarbox-amides. Coll. Czech Chem. Commun. 1999, 64, 288-298.

4. Mohamed A. Al-Omar, M.A.; Amr, A.E. Synthesis of some new pyridine-2,6-carboxamidederived Schiff bases as potential antimicrobial agents. Molecules 2010, 15, 4711-4721.

5. Attia, A.; Abdel-Salam, O.I.; Amr, A.E.; Stibor I.; Budesinsky, M. Synthesis and antimicrobial activity of some new chiral bridged macrocyclic pyridines. Egypt. J. Chem. 2000, 43, 187-201.

6. Wright, P.S.; Cross-Doersen, D.; Th'ng, J.P.; Guo, X.W.; Crissman, H.A.; Bradbury, E.M.; Montgomery, L.R.; Thompson, F.Y.; Loudy, D.E.; Johnston, J.O.; Bitonti, A.J. A ribonucleotide reductase inhibitor, MDL 101,731, induces apoptosis and elevates TRPM-2 mRNA levels in human prostate tumor xenografts. Exp. Cell Res. 1996, 222, 54-60.

7. Park, H.S.; Lin, Q.; Hamilton, A.D. Protein surface recognition by synthetic receptors: A route to novel submicromolar inhibitors for $\alpha$-chymotrypsin. J. Am. Chem. Soc. 1999, 121, 8-13.

8. Dowden, J.; Edwards, P.D.; Flack, S.S.; Kilbnurn, J.D. Synthesis and Binding Properties of a Macrocyclic Peptide Receptor. Chem. Eur. J. 1999, 5, 79-89.

9. Hassan, S.S.M.; Abou-Ghalia, M.H.; Amr, A.E.; Mohamed, A.H.K. Novel lead (II) selective membrane potentiometric sensors based on chiral 2,6-bis-pyridinecarboxamide derivatives. Talanta 2003, 60, 81-91.

10. Hassan, S.S.M.; Abou-Ghalia, M.H.; Amr, A.E.; Mohamed, A.H.K. Novel thiocyanate-selective membrane sensors based on di-, tetra-, and hexa-imidepyridine ionophores. Anal. Chim. Acta 2003, 482, 9-18.

11. Bayrak, H.; Demirbas, A.; Karaoglu, S.A.; Demirbas, N. Synthesis of some new 1,2,4-triazoles, their Mannich and Schiff bases and evaluation of their antimicrobial activities. Eur. J. Med. Chem. 2009, 44, 1057-1066.

12. Ashok, M.; Holla, B.S.; Boojary, B. Convenient one pot synthesis and antimicrobial evaluation of some new Mannich bases carrying 4-methylthiobenzyl moiety. Eur. J. Med. Chem. 2007, 42, 1095-1101. 
13. Karthikeyan, M.S.; Prasad, D.J.; Boojary, B.; Bhat, K.S.; Holla, B.S.; Kumari, N.S. Synthesis and biological activity of Schiff and Mannich bases bearing 2,4-dichloro-5-fluorphenyl moiety. Bioorg. Med. Chem. 2006, 14, 7482-7489.

14. Tozkoparan, B.; Küpeli, E.; Yeşilada, E.; Ertan, M. Preparation of 5-aryl-3-alkylthio-1,2,4triazoles and corresponding sulfones with antiinflammatory-analgesic activity. Bioorg. Med. Chem. 2007, 15, 1808-1814.

15. Labanauskas, L.; Udrenaite, E.; Gaidelis, P.; Brukštus, A. Synthesis of 5-(2,3,4-methoxy-phenyl)4H-1,2,4-triazole-3-thiol derivatives exhibiting anti-inflammatory activity. Farmaco 2004, 59, 255-259.

16. Navidpour, L.; Shafaroodi, H.; Abdi, K.; Amini, M.; Ghahremani, M.H.; Dehpour, A.R.; Shafiee, A. Design, synthesis, and biological evaluation of substituted 3-alkylthio-4,5-diaryl-4H-1,2,4triazoles as selective COX-2 inhibitors. Bioorg. Med. Chem. 2006, 14, 2507-2517.

17. Maxwell, J.R.; Wasdahl, D.A.; Wolfson, A.C.; Stenberg, V.I. Synthesis of 5-aryl-2H-tetrazoles, 5-aryl-2H-tetrazole-2-acetic acids, and [(4-phenyl-5-aryl-4H-1,2,4-triazol-3-yl)thio]acetic acids as possible superoxide scavengers and anti-inflammatory agents. J. Med. Chem. 1984, 27, $1565-1570$.

18. Amr, A.E.Z. Synthesis of some new linear and chiral macrocyclic pyridine carbazides as analgesic and anticonvulsant agents. Z. Naturforsch. 2005, 60b, 990-998.

19. Abou-Ghalia, M.H.; Amr, A.E.; Abdalah, M.M. Synthesis of some new ( $\mathrm{N}^{\alpha}$-dipicolinoyl)-bis-Lleucyl-DL-norvalyl linear tetra and cyclic octa bridged peptides as new anti-inflammatory agents. Z. Naturforsch. 2003, 58b, 903-910.

20. Amr, A.E.; Sayed H.H.; Abdulla, M.M. Synthesis and reactions of some new substituted pyridine and pyrimidine derivatives as analgesic, anticonvulsant and antiparkinsonian agents. Arch. Pharm. Chem. Life Sci. 2005, 338, 433-440.

21. Amr, A.E.; Abdel-Latif, N.A.; Abdulla, M.M. Synthesis and antiandrogenic activity of some new 3 -substituted androstano[17,16-c]-5 '-aryl-pyrazoline and their derivatives. Bioorg. Med. Chem. 2006, 14, 373-384.

22. Hammam, A.G.; Fahmy, A.F.M.; Amr, A.E.; Mohamed, A.M. Synthesis of novel tricyclic heterocyclic compounds as potential anticancer agents using chromanone and thiochromanone as synthons. Ind. J. Chem. 2003, 42B, 1985-1993.

23. Cruickshank, R.; Duguid, J.P.; Marion B.P.; Swain, R.H.A. Medicinal Microbiology, 12th ed.; Churchill Livingstone: London, UK, 1975; Volume II, pp. 196-202.

24. Abou-Zeid, A.A.; Shehata, Y.M. A simple technique for assaying antibiotics using methylene blue as an indicator. Ind. J. Pharm. 1969, 31, 72-75.

Sample Availability: Samples of the compounds are available from the authors.

(C) 2010 by the authors; licensee MDPI, Basel, Switzerland. This article is an open access article distributed under the terms and conditions of the Creative Commons Attribution license (http://creativecommons.org/licenses/by/3.0/). 